\title{
Does organizational adaptation really matter? How mission change affects the survival of U.S. federal independent agencies, 1933-2011
}

\author{
Arjen Boin ${ }^{1}$ | Celesta Kofman ${ }^{2}$ | Jeroen Kuilman ${ }^{3}$ | \\ Sanneke Kuipers $^{1}$ । Arjen van Witteloostuijn ${ }^{3,4,5}$
}

${ }^{1}$ Leiden University

${ }^{2}$ Independent researcher

${ }^{3}$ Tilburg University

${ }^{4}$ Antwerp University

${ }^{5}$ Cardiff University

\begin{abstract}
Public administration scholars tend to take for granted that organizational adaptation is important. This common notion that public organizations must adapt to stay alive has not been put to the test in the field of public administration, however. Intriguingly, organization ecologists find that adaptation does not matter and might even be counterproductive for individual organizations. They argue that the absence of adaptation-which they refer to as structural inertiaactually enhances the likelihood of survival. But organization ecologists focus mostly on nonpublic organizations. This prompts the question whether adaptation in public organizations really matters. In this article, we test these contrasting claims (while controlling for design features) on a population of U.S. federal independent public agencies $(n=142)$. Our findings suggest a subtle narrative. We conclude that proactive adaptation increases termination hazards. But inertia does not seem to significantly enhance survival chances.
\end{abstract}

\section{1 | THE PREMISE AND PROMISE OF ADAPTATION}

Adaptation features in many treatises on both public and private organizations. It is often presented, both explicitly and implicitly, as an organizational capacity that is key to both the performance and survival of organizations (Hood, 1991, p. 11; Kaufman, 1976, p. 69; Kettl, 2016; MacCarthaigh, 2014; Thompson, 1967). As John Gardner (1995, p. xi) put it: "Failure to face the realities of change brings heavy penalties. Individuals become imprisoned in their own rigidities. Great institutions deteriorate. Civilizations fall."

Anthony Downs (1967, p. 7) postulates that "no bureau can survive unless it is continually able to demonstrate that its services are worthwhile to some group with influence over sufficient sources to keep it alive." And bureaus can only accomplish this "if they are agile enough to undertake new and 
more viable functions before it is too late" (p. 22). In his standard work on organizations, Aldrich (1999, p. 194) observes that "an organization that cannot change in fundamental ways will constantly be at risk." In the literature on resilience, the ideal organization has the "capacity to change before the case for change becomes desperately obvious" (Hamel \& Välikangas, 2003, p. 513; cf. Boin \& Van Eeten, 2013; Duit, 2016). The assumed importance of adaptation has a Darwinian undertone: An organization needs to adapt constantly to preserve a life-sustaining fit with its environment (Fukuyama, 2014; Kettl, 2016; Wilson, 2002).

The necessity of adaptation is rarely questioned, either in academia or in practice. In fact, it is the absence of adaptation that invites criticism. The classic critique on the bureaucratic organization points to its "unadaptive" or "rigid" character (Perrow, 1986, p. 5; cf. Crozier, 1964; Merton, 1949). Jim March (1991) coins the term "competency traps" in describing a failure to renew. This line of criticism extends into the hubris thesis, which states that successful organizations are loath to change, become rigid, lose touch with their environment, and fall deeply (Collins, 2009).

The criticism, in turn, gives rise to proposals that aim to make rigid, change-resisting bureaucracies more adaptive. In his theory of institutional design, Goodin (1996, p. 40) advises "to design our institutions in such a way as to be flexible, to admit of 'learning by doing' and to evolve over time. Thus we might say revisability is one important principle of institutional design." Reform movements have emerged that seek to somehow "break" bureaucracy by "reinventing" it (e.g., Osborne \& Gaebler, 1992). Their manifestos typically include references to delegating, redesigning, introducing, and devising new processes or ways of working to create an "innovative and flexible" organization (Wolf, 1997).

But does adaptation really work? Is it really critical to the survival of public organizations? There is little empirical research to answer this question. It is clear that organizations change constantly (Blau, 1955; Moore \& Kraatz, 2011; Perrow, 1986, p. 166; Thompson, 1967). But it is not clear whether this adaptation is effective (and, if so, how). There is some research on the relation between adaptation and performance (Boyne, 2006), but the findings are far from conclusive (Baum \& Oliver, 1991, p. 194). Wolf (1997) finds that "adaptability contributes modestly to the effectiveness of agencies." But in their study of Texas school districts, Boyne and Meier (2009a) report that organizational adaptation had a negative impact on performance.

There is some evidence that adaptation enhances organizational survival (Bertelli, 2008; Greasley \& Hanretty, 2015). For instance, De Geus (1997) identifies adaptability as one of the factors that drives corporate longevity. In their study of British agency responses to termination threats, Dommett and Skelcher (2014) find that defense strategies mattered. In their study of New Deal agencies, Boin, Kuipers, and Steenbergen (2010) conclude that adaptation explained, at least partially, why some New Deal agencies lasted for decades, whereas others died young.

There is also evidence to the contrary. Organizational ecologists have shown that adaptation has negative effects, making survival less likely (Bogaert, Boone, Negro, \& van Witteloostuijn, 2016; Hannan \& Freeman, 1977, 1984, 1989; Wezel \& van Witteloostuijn, 2006). Their research suggests that inertia is a better way to weather turbulence than adaptation (cf. Boyne \& Meier, 2009b).

In this article, we study the effects of organizational adaptation in the public sector. More specifically, we study how adaptation affected organizational survival in a set of 142 U.S. federal independent agencies in the period 1933-2011. ${ }^{1}$ Our findings do not support the sweeping notion that adaptation increases the survival chances of public organizations. In fact, our findings suggest that proactive adaptation (prior to changes imposed by the legislator) undermines an organization's survival chances. But our findings do not support the notion that inertia is a safer strategy. Rather, it appears that "Wilsonian" responsiveness to legislative change is the best survival strategy. 


\section{2 | ADAPTATION VERSUS INERTIA}

In this section, we discuss two competing theories about the effects of adaptation. We articulate the mechanisms underlying these theories to explain why they yield opposing empirical predictions. We start with the idea that organizational adaptation should be rewarded with greater agency survival. We then present the idea that such adaptation is risky and increases the chances of demise.

\subsection{The logic of adaptation}

We define adaptation as the organizational capacity to implement changes that restore or maintain a fit with the ever-changing expectations and values of key stakeholders. We thus define adaptation as a goal-oriented activity, and not as the random outcome of small changes.

Many studies in organizational sociology and public administration suggest, if not assume, that only those organizations that continuously adapt in response to changes in their environment can stay alive (Child, 1972; Drazin \& van de Ven, 1985; Goodsell, 2011; Moore \& Kraatz, 2011). The underlying assumption is that organizations require a minimal degree of explicit and implicit support from key stakeholders; without the support of such stakeholders, organizations cannot attract the resources required to survive.

An emerging mismatch between the expectations of stakeholders and the perceived performance of an organization is thought to have negative consequences for a public organization. Such a mismatch may trigger intense discussion about the organization's way of operating, inviting change (Alink, Boin, \& 't Hart, 2001; Ansell \& Vogel, 2006; Crozier, 1964).

While many scholars consider adaptation important, they do not claim it is easy. Robert Merton (1949) famously described how public organizations attract a certain type of personality that resists change. Downs (1967, p. 9) argues that older organizations tend to be less flexible, "reducing the bureau's ability to adjust to new circumstances." It is hard to change the institutionalized features of an organization, especially when these embody proven success formulas.

In fact, it may be easier for public organizations not to change and to "rely on a certain amount of inertia" (Downs, 1967, p. 8). Public organizations can resist change by building autonomy (Hargrove \& Glidewell, 1990; Selznick, 1957; Wilson, 1989), creating a buffer between organizational routines and external influences (cf. Meyer \& Rowan, 1977; Thompson, 1967). But "few bureaus ever achieve such perfect autonomy" (Downs, 1967, p. 9).

Adaptation comes in different forms. It can be either proactive (anticipating the perceived need to change) or reactive (after a crisis or following the direct orders of stakeholders) (Ansell, Boin, \& Farjoun, 2015; Schön, 1973). Proactive change seems riskier, as there is no apparent need to instigate change. Leaders will have to work harder to convince employees of the need for change than is the case after an institutional crisis.

Adaptation can come in small steps (incremental change) or in a comprehensive radical reform program leading to paradigmatic change (Baumgartner \& Jones, 1993; Hall, 1993). Many scholars recognize a hierarchy of adaptation, assuming that small changes are easier to accomplish than large-scale, paradigmatic changes (e.g., Genschel, 1997; Hannan \& Freeman, 1984; Lindner \& Rittberger, 2003; Tushman, Newman, \& Romanelli, 1986). Yet, scholars also note that large-scale change is possible when crises provide so-called "windows of opportunity” (Alink et al., 2001; Cortell \& Peterson, 1999; Kingdon, 1984).

\subsection{The logic of inertia}

The ecology school in the field of organization theory offers a contrasting perspective on the effects of organization-level adaptation. These scholars argue that organizational adaptation is both risky and 
hard to achieve. Their research suggests that the absence of adaptation enhances an organization's survival chances. For an individual organization, weathering turbulence is therefore much wiser than changing to accommodate it (cf. Boyne \& Meier, 2009b).

Ecologists try to "understand the forces that shape organizational structures over long time spans" (Freeman \& Hannan, 1989, p. 426). Organizational adaptation is not one of those forces, these scholars contend. Rather, "most of the variability in organizational structures comes about through the creation of new organizations and organizational forms and the replacement of old ones" (Hannan \& Freeman, 1984, p. 150).

These scholars do not deny that organizations change. In fact, "organizational changes of some kinds occur frequently and organizations sometimes even manage to make radical changes in strategies and structures" (Hannan \& Freeman, 1984, p. 149). But such adaptations do not affect their survival chances. Effective adaptation happens at the (macro) population level rather than the (micro) organizational level: New forms emerge, rendering existing ones obsolete in the competition over scarce resources.

Ecology scholars do not believe that individual organizations are capable of adapting in an effective and timely manner to dynamic environments. Organizations are not "rational, flexible and speedy adapters to changing environmental circumstances" (Freeman \& Hannan, 1989, p. 426). Their research appears to confirm that individual organizations are "structurally inert" or "relatively inert"-meaning that they rarely have the capacity to make meaningful or timely adaptations (Aldrich, 1999, pp. 43-48).

There are at least three reasons why adaptation at the level of individual organizations is unlikely to be effective. First, the process of developing and implementing change always incurs a wide range of transaction costs (Barnett \& Carroll, 1995; Gingrich, 2015). Change proposals usually generate resistance, which "tend to generate short-run costs that are high enough that organizational leaders will forego the planned reorganization" (Hannan \& Freeman, 1977, p. 931). Organizational ecologists expect that the costs rise as one proceeds up the hierarchy from peripheral to core change. But it is these latter, more fundamental changes that are usually needed to stay afloat in dynamic environments.

A second reason is that organizational leaders do not have the information or cognitive capacities required to design the changes that are needed to fit a rapidly changing and complex environment—an assessment ecologists share with many public administration scholars. As Hannan and Freeman (1977, p. 931) remind us, "leaders do not obtain anything close to full information on activities within the organization and environmental contingencies facing the subunits." But even if there was an all-seeing leader, she would likely not have the intellectual capacities required to map out effective changes that keep organization and environment in a tight fit. Freeman and Hannan (1989, p. 426) thus reject what they call the "heroic images of managers" that we often encounter in the reform literature.

A third reason is timing. Even if organizations would manage to design and implement sensible changes, environmental dynamics tend to outpace these changes (Kelly \& Amburgey, 1991; Péli, 1997). Organizational leaders may be smart, but they cannot outsmart their environment. Organizations may change, but it is usually too little, too late (Sorge \& van Witteloostuijn, 2004). As Moore and Kraatz (2011, p. 850) argued in their study of the U.S. savings and loan industry, "the ability to change itself is no guarantee to adaptive success." 2

From an ecological perspective, it is risky for an organization to change in response to environmental shifts. Ecological scholars stress the benefits of stability, which they consider a valuable organizational characteristic. Stakeholders, from customers to politicians, expect organizations (private and public) to be accountable, reliable, and consistent. Hannan and Freeman (1984, p. 153) argue that "the modern world favors collective actors that can demonstrate or at least reasonably claim a capacity for reliable performance and can account rationally for their actions" (cf. Meyer \& Rowan, 1977). 
Adaptation undermines the legitimacy derived from accountability, reliability, and consistency. Organizations should therefore not change their identity or their legally sanctioned modus operandi.

Ecologists find that inert organizations - corporations that shun adaptation — are more likely to survive than their ever-adapting counterparts. It logically follows that organizational inertia-the absence of adaptation - is the prescribed survival strategy (Amburgey, Kelly, \& Barnett, 1993; Hannan \& Freeman, 1984; Wezel \& van Witteloostuijn, 2006).

The question is whether these findings hold for individual public organizations. We should keep in mind that the ecological perspective aims to explain "why there are so many (or few) kinds of organization" (Freeman \& Hannan, 1989, p. 430); they are less interested in the effects of adaptation (which is just one possible answer to their question; cf. Elston, 2014). Moreover, they are interested in populations - that is, in "aggregates of organizations rather than members" (Hannan \& Freeman, 1977, p. 934). A population - think of construction firms, educational organizations, voluntary associations, semiconductor manufacturers, or daily newspapers - is marked by a common form. Population ecology seeks to explain why certain organizational forms fit certain environments. Certain "fixed repertoires of action" work in certain environments. Shifting environments are nicer to some than to others. "The diversity of organizational forms is isomorphic to the diversity of the environments" (Hannan \& Freeman, 1977, p. 939).

\section{3 | TOWARD HYPOTHESES}

We are interested in studying the effects of adaptation on the survival chances of public organizations. We discuss two very different schools of thought. One assumes the critical importance of organizational adaptation: An organization must change to survive. The other school points out that individual adaptation is unlikely to be successful, and more likely to further the gap between performance and expectations. These scholarly traditions provide us with two possible, and opposing, effects:

\section{Hypothesis 1: A public organization's adaptation is positively associated with its likelihood of survival.}

Hypothesis 1alt: A public organization's adaptation is negatively associated with its likelihood of survival.

In our theoretical discussion, we speculated that the timing of an organization's adaptive efforts may matter. Proactive change is unforced and agency driven; it is not imposed on the organization by its political or regulatory environment. Reactive change is a direct reaction to an external (legal) intervention. Based on the public administration logic of adaptation, we may argue that proactive change is more likely to be effective than reactive change, as the former allows for a certain degree of latitude in shaping the way change is implemented (Ansell et al., 2015). The organizational ecology logic of inertia, in contrast, argues that proactive change is best avoided: Change should only be initiated, if at all, when enforced on the organization. This gives rise to the following hypotheses:

Hypothesis 2: Proactive change by a public organization is positively associated with its likelihood of survival.

Hypothesis 2alt: Proactive change by a public organization is negatively associated with its likelihood of survival.

Hypothesis 3: Reactive change by a public organization is positively associated with its likelihood of survival. 
Hypothesis 3alt: Reactive change by a public organization is negatively associated with its likelihood of survival.

\section{4 | RESEARCH DESIGN}

\subsection{Case selection}

We test our hypotheses on a set of 142 U.S. federal public agencies (see the Appendix for a complete list). ${ }^{3}$ We constructed a detailed data set of the federal public agencies that are listed in the U.S. Government Manual (USGM) during the period 1935-2011 as "independent agency" for at least 1 year of their existence. All these agencies have their own "entry" (section) in the USGM, which logs fairly detailed information that allows us to collect, code, and compare data on those agencies. ${ }^{4}$ The USGM contains information on "creation and authority," "purpose," and "organization." The information is annually supplied by the agency (by filling out detailed forms).

\section{2 | Independent variable: Adaptation}

In our empirical analysis, we conceptualize organizational adaptation as an intended effort to implement changes to minimize the gap between external expectations and the professed rationale of the organization's goals and actions. Such changes may be implemented because the organization is forced to do so by external pressure or because organizational leaders choose to do so.

As organizations change all the time, the question is what we should count as adaptive behavior. We consider mission change as an indicator of adaptive behavior. A mission indicates how an organization brings incompatible goals together. Following Selznick (1957), we assume that an organization's mission statement reflects its formal commitments (as viewed by that organization). We further assume that mission statements are not easily changed (Perrow, 1986; Selznick, 1957; Wilson, 1989). We assume that when an organization changes its mission statement, it reflects a shift in leadership perception of core values and goals (Aldrich, 1999; Goodsell, 2011; Selznick, 1957; Suddaby \& Greenwood, 2005; Wilson, 1989). Mission change thus reflects organizationlevel adaptive capacity.

For each year after 1933, we used USGM information on each U.S. federal independent agency to trace and register annual mission changes. We looked for additions to mission statement and removals from mission statement. Each USGM entry was examined for newly stated purposes in its distinctly itemized mission statement (either stated separately or under the subcategory "purpose"). Each new purpose was counted as an addition to the mission statement on its first appearance in a USGM entry for that agency in a given year. We coded additions in absolute numbers. Similarly, we coded the number of purposes that were removed from the mission statement when compared to the agency's mission statement of the previous year (again, in absolute numbers). We differentiate between "minor" mission change (one change in the mission statement) and "major" mission change (two or more changes).

As expected, it appears harder to make more fundamental changes: We counted 153 major changes and 1,029 minor changes. On average, agencies saw one minor mission change in 5 years and one major change in 20 years. Intriguingly, there is quite some variance in adaptive behavior. Forty-two agencies never changed their mission ( 6 did it once, and 12 agencies did it twice). This seems to confirm the idea that organizations tend to be inert. Yet, 13 agencies changed their mission at least 20 times. 
We are also interested to see if the timing of adaptation matters. Does unprompted change (before a legislative intervention) or prompted change (in reaction to, and hence after, a legislative intervention) have a different effect on survival? We registered the number of legislative interventions introduced to the organization. This information can be found in the USGM. ${ }^{5}$ We then make a distinction between proactive change (1- or 2-year lead), contemporaneous change (in the year of legislative intervention) and reactive change (1- or 2-year lag) vis-à-vis legislative interventions targeting the focal agency.

\section{3 | Dependent variable: Survival}

To study the effects of adaptation, we focus on survival chances or durability of U.S. federal independent public agencies. We define durability as the likelihood of an agency being terminated in a given year. Defining termination (and creation) of organizations is no easy task. We kept our definitions as closely as possible to those of scholars who struggled with this challenge before us (e.g., Carroll \& Delacroix, 1982; Greasley \& Hanretty, 2015; Lewis, 2002, 2003; MacCarthaigh, 2014; Meyer, 1985; Rolland \& Roness, 2011).

We consider organizations terminated when they are explicitly mentioned as terminated or abolished in the USGM (and without any indication of continuity beyond this official termination), split into two or more new organizations (secession), absorbed into another office, or merged with another office. We took the date specified by law or executive order (if available) as end date, and otherwise coded the termination date according to the USGM. ${ }^{6}$

Seventy-four of the 142 agencies (52\%) that were present in the USGM since 1933 had ceased to exist on December 31, 2011. ${ }^{7}$ The presence of survivors implies right censorship, which means that the outcome in terms of survival is unknown. The 20 cases (14\%) that were established before 1933 are left-censored. Fifteen percent of the population $(n=22)$ did not "live" longer than 5 years. Most terminated agencies ( $n=41 ; 55 \%$ of all terminated agencies) were abolished within 12 years after their creation. Eight of the terminated agencies were merged, replaced, or otherwise changed formally and structurally. Three were replaced by a different agency with similar functions $(n=3 ; 4 \%)$, 4 were absorbed into a larger agency $(n=4 ; 5 \%)$, and just 1 merged with an agency of equal size and responsibilities $(n=1 ;<1 \%)$.

\section{4 | Control variables}

There are, of course, other explanations for survival. The most prominent alternative explanation is offered by Lewis (2002, p. 103; see also Lewis, 2003, 2004), who shows that "brute public authority to insulate agencies from the influence of other actors" enhanced survival chances in his population of American federal government organizations. According to Lewis (2004), organizations that are properly "hardwired" at birth live longer. His findings suggest that institutional birth features matter more than performance or adaptation later in life. If we want to study the effects of adaptation, we must control for this alternative explanation.

On creation, many agencies are equipped with a commission or board structure, as opposed to a single administrator, with the intention of insulating them from political interference (Lewis, 2004). To control for these differences in governing structures, we differentiated between agencies that at time of birth were endowed with a board or commission structure (coded 1), and those agencies that are not (coded 0). Each agency description in the USGM commences with a listing of job titles in which board and commission members are mentioned in a separate section.

Another design variable for which we control is the presence or absence of a sunset clause, which is a provision that specifies when an organization will cease to exist. A sunset clause, assigned a 1 
code, limits the expected lifespan of an agency. We scored any formal manifestation of transient intentions for the agency as the presence of a sunset clause. These include stipulations about a fixed budget for the entire lifespan, attainment of a specific goal, or an official cutoff date. If none of these preconditions are mentioned in the first listing of USGM, we coded a 0.

Following Lewis (2003), we also control for legislative origin. Agencies that are created after lengthy legislative procedures, involving heavy scrutiny and majority requirements, are thought to be less susceptible to termination than those agencies created by executive actions. To determine to which extent the legislature was involved in the creation process of agencies in our population, we traced the inception mandates of each agency in the USGM and in the USGM's History of Agency Organizational Changes (2011). We coded agencies initiated by act with a 1 as having a "strong legislative origin," those that had a reorganization plan at their basis with a 2, those established by an executive order with a 3, and those initiated by departmental or military order, which arguably could be classified as having the weakest legislative origin, with a code 4.

To control for agency size, we used the Budget of the United States Government (1933-2011) to retrieve the budgets of all agencies for each year during their existence. After calculating the budget median of our population, we ranked the agencies from smallest to largest budget. The agencies in the first quartile are categorized as a small budget agency (coded 1), and agencies in the second, third, and fourth quartiles are considered to be large budget agencies (coded 0).

In times of war, federal budget routines tend to be disturbed. Hence, the years of the following wars are coded as war years (coded 1): World War II (1941-1945), Korean War (1950-1953), Vietnam War (1965-1975), Gulf War (1990-1991), Afghanistan War (2001-2011), and the Iraq War (2003-2011).

\section{5 $\mid$ The model}

We used event-history analysis (Tuma \& Hannan, 1984) to empirically estimate the termination or mortality hazard of each agency in our population. We formally define mortality hazard as:

$$
\mu(u)=\lim _{\Delta u \rightarrow 0} \frac{\operatorname{Pr}(\operatorname{term}(u+\Delta u) \mid \text { noterm }(u))}{\Delta u},
$$

which reads as the likelihood that an agency ceases to exist between its age $u$ and $u+\Delta u$, provided that it did not exit at or prior to $u$. We use a semiparametric Cox proportional hazard rate specification (Cox, 1972) in modeling the mortality hazard, which is a product of an unspecified baseline hazard, $\mu_{0}(t)$, and a vector $\boldsymbol{x}_{\boldsymbol{t}}$ specifying the influences of covariates:

$$
\mu(t)=\mu_{0}(t) \exp \left(\boldsymbol{\beta}^{\prime} \mathbf{x}_{t}\right)
$$

Results not reported here indicate that qualitatively similar results are obtained when employing piecewise exponential models (results available on request).

\section{5 | FINDINGS}

We present our findings in a set of tables. Table 1 provides means, standard deviations, minimum and maximum values, and correlations. Table 2 presents the results of our event-history analysis. We use four models. Model 1 shows the effects of the control variables. Model 2 takes into account the pair of adaptation variables relating to additions and removals in mission statements. Models 3 and 4 include the variables related to the timing of mission change vis-à-vis legislative intervention. We report odds ratios. A coefficient below 1 implies a positive effect on the likelihood of survival; a coefficient above 1 indicates a negative impact. 


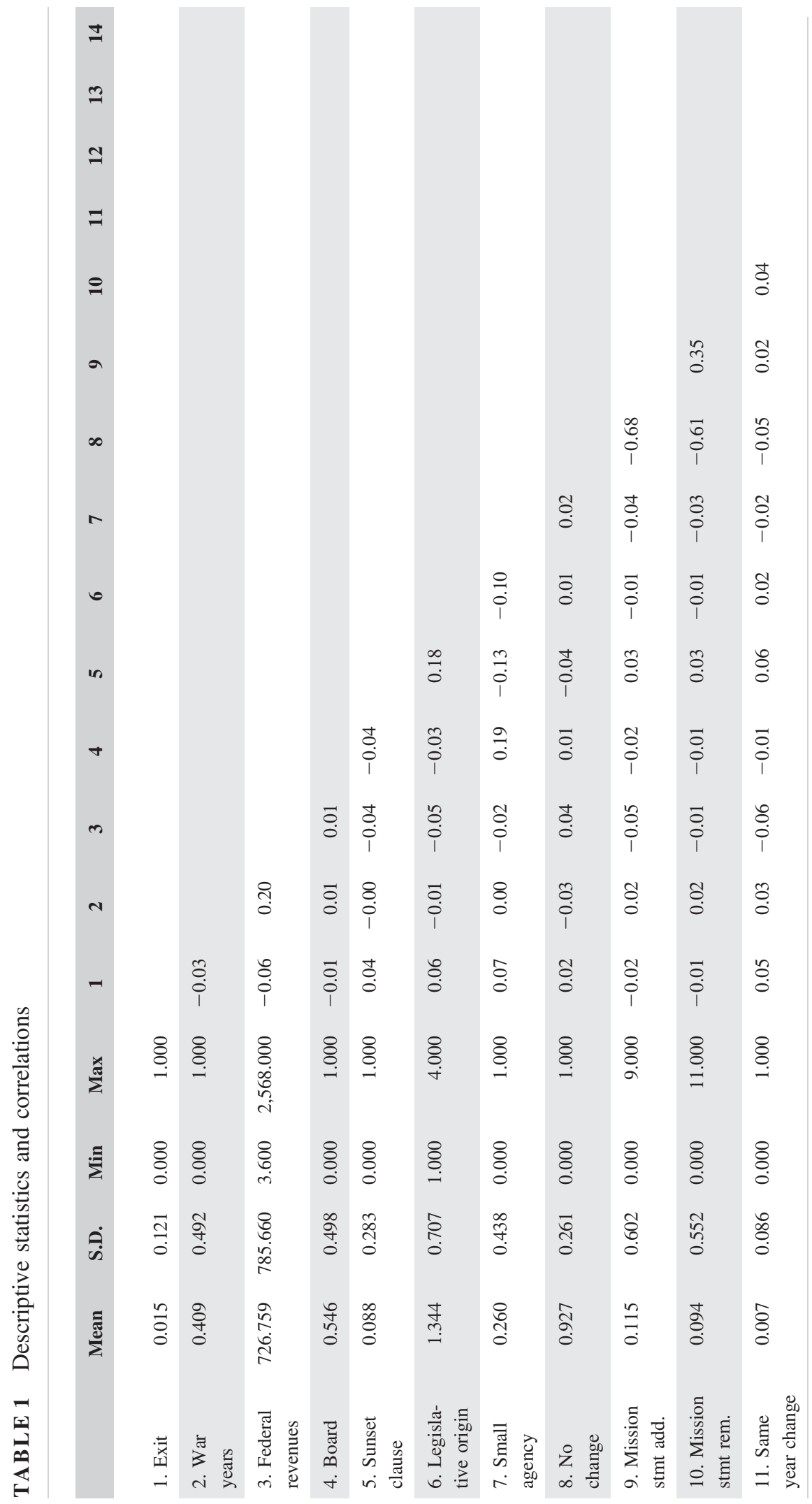




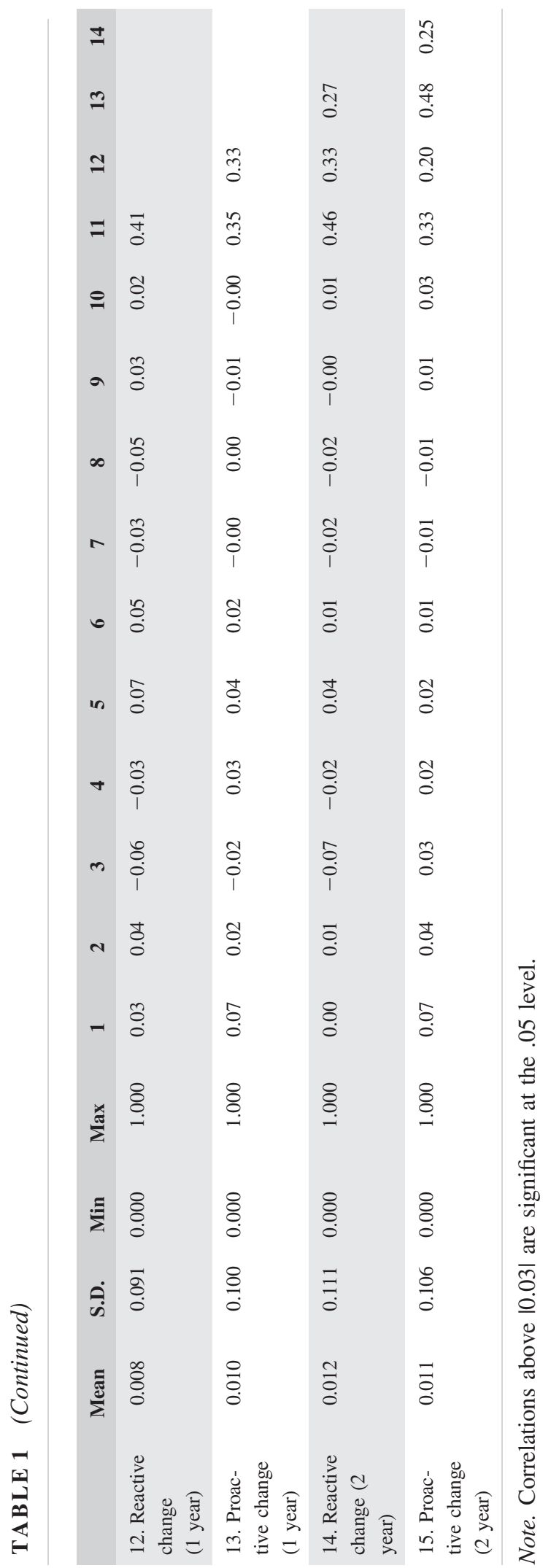


TABLE 2 Cox proportional hazards models

\begin{tabular}{|c|c|c|c|c|}
\hline & (1) & (2) & (3) & (4) \\
\hline \multirow{2}{*}{ War years } & 0.91 & 0.91 & 0.90 & 0.90 \\
\hline & $(0.24)$ & $(0.24)$ & $(0.24)$ & $(0.24)$ \\
\hline \multirow[t]{2}{*}{ Federal revenues } & 1.00 & 1.00 & 1.00 & 1.00 \\
\hline & $(0.00)$ & $(0.00)$ & $(0.00)$ & $(0.00)$ \\
\hline \multirow[t]{2}{*}{ Board } & 0.68 & 0.68 & $0.65 \dagger$ & 0.67 \\
\hline & $(0.17)$ & $(0.16)$ & $(0.16)$ & $(0.16)$ \\
\hline \multirow[t]{2}{*}{ Sunset clause } & $2.81 * *$ & $2.78^{* *}$ & $2.49 *$ & $2.67 * *$ \\
\hline & $(1.02)$ & $(1.00)$ & $(0.93)$ & $(0.99)$ \\
\hline \multirow{2}{*}{ Weak legislative origin } & $1.57 * *$ & $1.57 * *$ & $1.56^{* *}$ & $1.56^{* *}$ \\
\hline & $(0.19)$ & $(0.19)$ & $(0.19)$ & $(0.19)$ \\
\hline \multirow[t]{2}{*}{ Small (budget) agency } & $3.29 * *$ & $3.24 * *$ & $3.13^{* *}$ & $3.15^{* *}$ \\
\hline & $(0.83)$ & $(0.81)$ & $(0.79)$ & $(0.80)$ \\
\hline \multirow[t]{2}{*}{ No change } & 2.95 & 1.65 & 1.70 & 2.41 \\
\hline & $(2.08)$ & $(2.07)$ & $(2.13)$ & $(3.10)$ \\
\hline \multicolumn{5}{|l|}{ Magnitude of change } \\
\hline \multirow{2}{*}{ Mission statement add. } & & 0.40 & 0.39 & 0.43 \\
\hline & & $(0.37)$ & $(0.33)$ & $(0.33)$ \\
\hline \multirow[t]{2}{*}{ Mission statement rem. } & & 1.14 & 1.13 & 1.19 \\
\hline & & $(0.30)$ & $(0.32)$ & $(0.31)$ \\
\hline \multicolumn{5}{|l|}{ Relative timing of change } \\
\hline \multirow[t]{2}{*}{ Same-year change } & & & $3.58 \dagger$ & $8.75^{* *}$ \\
\hline & & & $(2.33)$ & $(5.33)$ \\
\hline \multirow[t]{2}{*}{ Reactive change (1-year lag) } & & & 0.23 & \\
\hline & & & $(0.22)$ & \\
\hline \multirow[t]{2}{*}{ Proactive change (1-year lead) } & & & $7.43^{* *}$ & \\
\hline & & & $(3.23)$ & \\
\hline \multirow[t]{2}{*}{ Reactive change (2-year lag) } & & & & $0.12 *$ \\
\hline & & & & $(0.13)$ \\
\hline \multirow[t]{2}{*}{ Proactive change (2-year lead) } & & & & $4.06 * *$ \\
\hline & & & & $(1.90)$ \\
\hline Log likelihood & -309.07 & -308.29 & -302.50 & -301.72 \\
\hline $\mathrm{Chi}^{2}$ & 45.75 & 68.88 & 85.88 & 94.51 \\
\hline AIC value & 632.14 & 634.58 & 629.00 & 627.44 \\
\hline Observations & 4,885 & 4,885 & 4,885 & 4,885 \\
\hline
\end{tabular}

Note. Hazard ratios are reported; robust standard errors in parentheses.

$\dagger p<.10 . * p<.05$. $* * p<.01$. 
Surprisingly, we do not find any evidence that adaptation matters, either by enhancing or limiting the chances of survival (Hypotheses 1 and 1alt). Although additions to the mission statement appear to be consistently negatively related to the likelihood of termination, and removals from the mission statement seem to positively affect the hazard, both effects are not statistically significant. We must therefore conclude that mission change does not affect the likelihood of survival. At the same time, we do not find any effects for inertia.

When we take into account the timing of mission change (Hypotheses 2 and 3), we must conclude that proactive change is very risky. Model 3 shows that changing the mission statement a year prior to a legislative change significantly elevates the mortality hazard by over 7 times. Even the co-occurrence of mission change and legislative intervention in the same year significantly undermines survival chances. ${ }^{8}$ Reactive change with a 1 -year lag, in contrast, lowers the mortality hazard (marginally significant at $p<.10)$. This supports Hypothesis 2alt.

When we extend the lead and lagged effects from 1 year to 2 years (Model 4), we find similar results. This extension should deal better with concerns about autocorrelation and multicollinearity, and turns out to have substantially better model fit ( -302.5 vs. -301.7 , with identical degrees of freedom). Changing an agency's mission statement 2 years a priori again proves to be extremely risky. Mission statement changes in the same year as a legislative intervention are still statistically significant and positive, suggesting a greater mortality hazard when the two coincide. Reactive change with a lag of 2 years in turn appears again to lower mortality, providing evidence for Hypothesis 3. All this suggests that responsive agencies are much less likely to be sanctioned via termination than proactive agencies (we return to this in the Discussion).

The control variables do not produce surprises. Small agencies (those in the smallest quartile in terms of budget) are most vulnerable to termination. The agencies that were started with a sunset clause and those with a weak legislative origin ran a higher risk of being terminated. ${ }^{9}$ The other control variables are nonsignificant in all four model specifications.

We ran a series of robustness checks, reported in Table A1 in the Appendix. Basically, our results are not affected by: (a) including a public corporation dummy (Model 5), (b) adding a control for young agencies (a dummy for agencies that exited before turning 5; Model 6), (c) using different size quartiles (Model 7), (d) removing agencies established with sunset clauses (Model 8), and (e) entering two proxies for political turnover (as captured by dummies for unfriendly president and unfriendly majority; Model 9).

\section{6 | DISCUSSION: ORGANIZATIONAL ADAPTATION AND INSTITUTIONAL DYNAMICS}

This article's central question is whether adaptation matters for public sector organizations. We started out with the common assumption in the public administration literature that adaptation is important if public organizations are to survive and prosper. We contrasted this assumption with the organizational ecology argument that organizational adaptation will harm rather than enhance a public organization's survival chance. We examined both perspectives on adaptation in the population of 142 U.S. federal independent agencies in the period 1933-2011, focusing on mission change as a solid indicator of an organization's capacity to adapt. In addition, we looked into the impact of the timing of adaptation.

Our findings are quite surprising. It turns out that reactive change vis-à-vis legislative intervention enhances the odds of survival; but proactive mission change ( 1 or 2 years before the legislative intervention) and contemporaneous change (in the year of the intervention) substantially increase the likelihood of termination. Intriguingly, this would imply that public 
agencies should not engage in proactive change (cf. Ansell et al., 2015). It is better to react to legislative intervention by adapting the mission accordingly, preferably after some time has passed.

This finding goes against the grain of many studies that prescribe an active role for bureaucratic leaders, casting them as "entrepreneurs" (Boin, 2001; Hargrove \& Glidewell, 1990; Ricucci, 1995). Our findings suggest that bureaucratic rule following-bureaucratic responsiveness to political decisions-better serves the interest of a public organization.

Why is proactive change so risky? There are at least two possible explanations. First, agencies that adapt proactively take a calculated risk. They change a mission that has not been subjected to political scrutiny and that has not been delegitimized. Such change is therefore likely to attract political attention, possibly nurturing a perception that the organization has problems. It feeds on the idea that only underperforming agencies would change their mission (Andrews, Boyne, \& Enticott, 2006; Boyne, 2006). A second reason lies in the costs of reorganization (a well-documented impediment to reform); smart organizations only do this when they absolutely must.

It is possible that we did not adequately measure organizational adaptation. We looked at changes to the mission of an organization, assuming that this type of change is an indicator of "core" adaptation. But organizations may well adapt constantly, and much more effectively, by a series of small, incremental changes in policies and tools (second-order or peripheral changes that are much harder to measure).

Also, we need to be cautious about the divergence between "talk" and "action" in organizations (Brunsson, 1989). It may well be that the mission, and the adaptation thereof, masks what the organization really does. We need in-depth qualitative case studies to probe into such dynamics (see, for fascinating examples, Doig, 2001; Hargrove, 1994).

Our study did not explicitly measure levels of political support for public organizations. Some organizations could be at risk for termination because they have weaker support whereas other organizations can be inert because they enjoy high levels of support. An in-depth qualitative approach is needed to find out if external support or interest group pressure provide alternative explanations for both adaptation and survival.

Finally, it is possible that the extent of environmental change is not fully captured by equating it to legislative interventions. Our notion of preemptive change does take into account the possibility that agencies respond to other environmental prompts such as funding change, presidential unilateral action, and court cases. We assumed that changes in the external environment eventually translate into legislative changes, but the relative inactivity of Congress in recent years casts some doubt on this assumption.

These limitations point to promising avenues of future research. One way to make progress is to code the perceptions of an agency's performance (cf. Baumgartner \& Jones, 1993). It would also be interesting to code for different types of organizational adaptation strategies, both "deep" or fundamental and "superficial" or incremental, to explore whether the nature of change and the temporal patterns of change types may matter. Future research could also compare our findings with studies of similar populations in other countries (Laegreid, Rolland, Roness, \& Agotnes, 2010; MacCarthaigh, 2014; Yesilkagit \& Christensen, 2011), and of other types of public organizations.

Our findings offer inconclusive support for the insights derived from organizational ecology. We find no evidence that inertia has an effect on survival chances. These insights have been much applied in the business and sociology literatures, but not so much in the study of public organizations. Future work should extend the ecological analysis of public organizations by further exploring alternative mechanisms, a prominent example being the density dependence conception of organizational 
selection, which organizational ecology argues is a much more powerful force than organizational adaptation (Hannan \& Freeman, 1977, 1989).

This article is one of the first to investigate the effects of adaptation on survival. Our findings cast doubt on the widespread belief in the benefits of organizational adaptation. It may well be that future research rescues the belief in adaptation from the forces of inertia. In the absence of more positive findings, we must caution against perspectives that sing the praise of proactive adaptation. Waiting for a clear order-Wilsonian responsiveness-may be most beneficial to an agency's survival prospects.

\section{ACKNOWLEDGMENT}

We thank Alasdair Roberts for selecting four critical yet thoughtful reviewers whose comments were greatly helpful in improving this article. Rachel Ashworth, Peter Mortensen, and participants at the Structure of Government conference in Jerusalem (2014) and the 30th EGOS Colloquium (2014) provided us with valuable comments on previous drafts.

\section{NOTES}

${ }^{1}$ To be sure, we are not seeking to explain organizational survival. We want to study whether adaptation has effects, and we study these effects in terms of survival.

${ }^{2}$ Moore and Kraatz (2011) argue that adaptation is likely to be more effective when organizations change slowly in response to their environment, and stay close to their organizational competences (p. 861).

${ }^{3}$ We excluded cabinet bureaus because the USGM contains little or inconsistent information on them. One might also argue that their dependence on the whims of executives is itself an explanatory factor for survival. Neither agency components nor suboffices were included, as by their very nature they perish much more easily and frequently than the independent agencies they are part of.

${ }^{4}$ For reasons of size, organizational unity, and distinctiveness, we excluded: (a) bilateral or multilateral organizations; (b) monuments and celebrations (e.g., bicentennials) commissions; (c) foreign claims commissions; (d) committees, advisory councils, or boards consisting of only ex officio members (such as the Secretary of Defense and State together advising the president as "Council X or Y") or functionaries or representatives of other organizations, which do not form a standing organization; and (e) agencies with only a single state purpose (e.g., Delaware River Basin Commission, Virginia State Boundary Commission, and Alaska Power Administration).

${ }^{5}$ Legislative intervention can be introduced by executive authority (executive or departmental order; reorganization plans) or legislative authority (the act of law). Following Lewis (2003), we take intervention by act of law as an indicator of important shifts in an agency's environment.

${ }^{6}$ We took a sample of 20 cases from our population (representing both "short-lived" and durable agencies) and checked intercoder reliability between the two researchers who did all the coding work. Out of 12,800 observations, we found 665 differences, which results in intercoder reliability of $94.8 \%$. Each difference in observation (even if this pertained to only a fraction difference on a code scale) was interpreted most strictly, as full difference.

${ }^{7}$ Due to unavailability of data for 2012/2013, we decided to take December 31, 2011 as an artificial end point.

${ }^{8}$ Co-concurrence may actually indicate a form of proactive change, due to the lag time between legislative change and the materialization of mission changes in the USGM.

${ }^{9}$ As innovation and reinvention might be less likely in temporary organizations, we estimated the same set of models on agencies that did not have an expiration date. More specifically, we tested the models on the population without sunset clauses (excluding 17 cases). We did not find a difference in effects. 


\section{REFERENCES}

Aldrich, H. E. (1999). Organizations evolving. London, UK: Sage.

Alink, F., Boin, A., \& 't Hart, P. (2001). Institutional crises and reform in policy sectors. Journal of European Public Policy, 8, 286-306.

Amburgey, T. L., Kelly, D., \& Barnett, W. P. (1993). Resetting the clock: The dynamics of organizational change and failure. Administrative Science Quarterly, 38, 51-73.

Andrews, R., Boyne, G. A., \& Enticott, G. (2006). Performance failure in the public sector: Misfortune or mismanagement? Public Management Review, 8, 273-296.

Ansell, C., Boin, A., \& Farjoun, M. (2015). Dynamic conservatism: How institutions change to remain the same. In M. Kraatz (Ed.), Research in the sociology of organizations: Special issue. Institutions and ideals-Philip Selznick's legacy for organizations studies (Vol. 44, Issue 1, pp. 89-119). Bingley, UK: Emerald.

Ansell, C., \& Vogel D. (Eds.). (2006). What's the beef? The contested governance of European food safety. Cambridge, MA: MIT Press.

Barnett, W. P., \& Carroll, G. R. (1995). Modeling internal organizational change. Annual Review of Sociology, 21, 217-236.

Baum, J. A. C., \& Oliver, C. (1991). Institutional linkages and organizational mortality. Administrative Science Quarterly, 36, 187-218.

Baumgartner, F., \& Jones, B. D. (1993). Agendas and instability in American politics. Chicago, IL: University of Chicago Press.

Bertelli, A. M. (2008). Credible governance? Transparency, political control, the personal vote and British Quangos. Political Studies, 56, 807-829.

Blau, P. (1955). The dynamics of bureaucracy. Chicago, IL: University of Chicago Press.

Bogaert, S., Boone, C., Negro, G., \& van Witteloostuijn, A. (2016). Organizational form emergence: A meta-analysis of organizational ecology's theory of legitimation. Journal of Management, 42, 1344-1373.

Boin, A. (2001). Crafting public institutions: Leadership in two prison systems. Boulder, CO: Rienner.

Boin, A., Kuipers, S., \& Steenbergen, M. (2010). The life and death of public organizations: A question of design? Governance, 23, 385-410.

Boin, A., \& Van Eeten, M. (2013). The resilient organization. Public Management Review, 15, 429-445.

Boyne, G. A. (2006). Strategies for public service turnaround: Lessons from the private sector. Administration and Society, 38, 365-388.

Boyne, G. A., \& Meier, K. J. (2009a). Environmental change, human resources and organizational turnaround. Journal of Management Studies, 46, 835-863.

Boyne, G. A., \& Meier, K. J. (2009b). Environmental turbulence, organizational stability and public service performance. Administration \& Society, 40, 799-824.

Brunsson, N. (1989). The organization of hypocrisy: Talk, decisions and action in organizations. New York, NY: Wiley.

Carroll, G. R., \& Delacroix, J. (1982). Organizational mortality in the newspaper industries of Argentina and Ireland: An ecological approach. Administrative Science Quarterly, 27, 169-198.

Child, J. (1972). Organizational structure, environment and performance: The role of strategic choice. Sociology, 6, 1-22.

Collins, J. (2009). How the mighty fall. New York, NY: HarperCollins.

Cortell, A. P., \& Peterson, S. (1999). Altered states: Explaining domestic institutional change. British Journal of Political Science, 29, 177-203. 
Cox, D. (1972). Regression models and life tables. Journal of the Royal Statistical Society, Serial B, 34, 187-220.

Crozier, M. (1964). The bureaucratic phenomenon. Chicago, IL: University of Chicago Press.

De Geus, A. (1997). The living company. Cambridge, MA: Harvard Business School Press.

Doig, J. W. (2001). Empire on the Hudson. New York, NY: Columbia University Press.

Dommett, K., \& Skelcher, C. (2014). Opening the black box of administrative reform: A strategicrelational analysis of agency responses to termination threats. International Public Management Journal, 17, 540-563.

Downs, A. (1967). Inside bureaucracy. Boston, MA: Little, Brown.

Drazin, R., \& van de Ven, A. (1985). Alternative forms of fit in contingency theory. Administrative Science Quarterly, 30, 514-539.

Duit, A. (2016). Resilience thinking: Lessons for public administration. Public Administration, 94, 364-380.

Elston, T. (2014). Not so “arm's length": Reinterpreting agencies in UK central government. Public Administration, 92, 458-476.

Fukuyama, F. (2014). America in decay: The sources of political dysfunction. Foreign Affairs, 93, 3-26.

Freeman, J., \& Hannan, M. T. (1989). Setting the record straight on organizational ecology: Rebuttal to young. American Journal of Sociology, 95, 425-439.

Gardner, J. W. (1995). Self-renewal: The individual and the innovative society. New York, NY: Norton.

Genschel, P. (1997). The dynamics of inertia: Institutional persistence and change in telecommunications and health care. Governance, 10, 43-66.

Gingrich, J. (2015). Varying costs to change? Institutional change in the public sector. Governance, 28, $41-60$.

Goodin, R. E. (1996). Institutions and their design. In R. E. Goodin (Ed.), The theory of institutional design (pp. 1-53). Cambridge, UK: Cambridge University Press.

Goodsell, C. T. (2011). Mission Mystique: Belief systems in public agencies. Bloomington: Indiana University Press.

Greasley, S., \& Hanretty, C. (2015). Credibility and agency termination under parliamentarism. Journal of Public Administration Research and Theory, 26, 159-173.

Hall, P. A. (1993). Policy paradigms, social learning, and the state: The case of economic policymaking in Britain. Comparative Politics, 25, 275-296.

Hamel, G., \& Välikangas, L. (2003). The quest for resilience. In W. W. Burke, D. G. Lake, \& J. W. Paine (Eds.), Organization change, a comprehensive reader (pp. 512-532). San Franciso, CA: Jossey-Bass.

Hannan, M. T., \& Freeman, J. (1977). The population ecology of organizations. American Journal of Sociology, 82, 929-964.

Hannan, M. T., \& Freeman, J. (1984). Structural inertia and organizational change. American Sociological Review, 49, 149-164.

Hannan, M. T., \& Freeman, J. (1989). Organizational ecology. Cambridge, MA: Harvard University Press.

Hargrove, E. (1994). Prisoners of myth: The leadership of the Tennessee Valley Authority, 1933-1990. Princeton, NJ: Princeton University Press.

Hargrove E. C., \& Glidewell, J. C. (Eds.). (1990). Impossible jobs in public management. Lawrence: University Press of Kansas.

Hood C. (1991). A public management for all seasons? Public Administration, 69, 3-19.

Kaufman, H. (1976). Are government organizations immortal? Washington, DC: Brookings Institution Press.

Kelly, D., \& Amburgey, T. (1991). Organizational inertia and momentum-A dynamic model of strategic change. Academy of Management Journal, 34, 591-612. 
Kettl, D. F. (2016). Escaping Jurassic government: How to recover America's lost commitment to competence. Washington, DC: Brookings Institution Press.

Kingdon, J. (1984). Agendas, alternatives, and public policies. Ann Arbor: University of Michigan Press.

Laegreid, P., Rolland, V. W., Roness, P. G., \& Agotnes, J.-E. (2010). The structural anatomy of the Norwegian State 1985-2007. In P. Laegreid \& K. Verhoest (Ed.), Governance of public sector organizations (pp. 21-43). Basingstoke, UK: Palgrave Macmillan.

Lewis, D. E. (2002). The politics of agency termination: Confronting the myth of agency immortality. Journal of Politics, 64, 89-107.

Lewis, D. E. (2003). Presidents and the politics of agency design. Palo Alto, CA: Stanford University Press.

Lewis, D. E. (2004). The adverse consequences of the politics of agency design for presidential management in the United States. British Journal of Political Science, 34, 377-404.

Lindner, J., \& Rittberger, B. (2003). The creation, interpretation and contestation of institutions-Revisiting historical institutionalism. Journal of Common Market Studies, 41, 457-473.

MacCarthaigh, M. (2014). Agency termination in Ireland: Culls and bonfires, or life after death? Public Administration, 92, 1017-1037.

March, J. G. (1991). Exploration and exploitation in organizational learning. Organization Science, 2, 71-87.

Merton, R. K. (1949). Bureaucratic structure and personality. In R. K. Merton (Ed.), Social theory and social structure (pp. 196-206). New York, NY: Free Press.

Meyer, J. W., \& Rowan, B. (1977). Institutionalized organizations: Formal structure as myth and ceremony. American Journal of Sociology, 83, 340-363.

Meyer, M. W. (1985). Limits to bureaucratic growth. New York, NY: De Gruyter.

Moore, J. H., \& Kraatz, M. S. (2011). Governance form and organizational adaptation: Lessons from the savings and loan industry in the 1980s. Organization Science, 22, 850-868.

Osborne, D., \& Gaebler, T. (1992). Reinventing government. Reading, MA: Addison-Wesley.

Péli, G. (1997). The niche hiker's guide to population ecology: A logical reconstruction of organization ecology's niche theory. Sociological Methodology, 27, 1-46.

Perrow, C. B. (1986). Complex organizations. New York, NY: Random House.

Ricucci N . (1995). Unsung heroes: Federal execucrats making a difference. Washington, DC: Georgetown University Press.

Rolland, V., \& Roness, P. G. (2011). Mapping organizational change in the state. International Review of Public Administration, 34, 399-409.

Schön, D. (1973). Beyond the stable state. Harmondsworth, UK: Penguin.

Selznick, P. (1957). Leadership in administration. Berkeley: University of California Press.

Sorge, A., \& van Witteloostuijn, A. (2004). The (non)sense of organizational change: An essay about universal management hypes, sick consultancy metaphors, and healthy organization theories. Organization Studies, 25, 1205-1231.

Suddaby, R., \& Greenwood, R. (2005). Rhetorical strategies of legitimacy. Administrative Science Quarterly, 50, 35-67.

Thompson, J.D. (1967). Organizations in action: Social science bases of administrative theory. New Brunswick, NJ: Transaction.

Tuma, N. B., \& Hannan, M. T. (1984). Social dynamics: Models and methods. Orlando, FL: Academic Press.

Tushman, M. L., Newman, W. H., \& Romanelli, E. (1986). Convergence and upheaval: Managing the unsteady pace of organizational evolution. California Management Review, 29, 1-16. 
Wezel, F. C., \& van Witteloostuijn, A. (2006). From scooters to choppers: Product portfolio change and organizational failure, evidence from the UK motorcycle industry 1895-1993. Long Range Planning, 39, 11-28.

Wilson, D. S. (2002). Darwin's cathedral. Chicago, IL: University of Chicago Press.

Wilson, J. Q. (1989). Bureaucracy. New York, NY: Basic Books.

Wolf, P. J. (1997). Why must we reinvent the federal government? Putting historical development claims to the test. Journal of Public Administration Research and Theory, 7, 353-388.

Yesilkagit, K., \& Christensen, J. (2011). Institutional design and formal autonomy. Journal of Public Administration Research and Theory, 20, 53-74.

\section{APPENDIX}

TABLE A1 Robustness checks

\begin{tabular}{|c|c|c|c|c|c|}
\hline & $\begin{array}{l}\text { (5) } \\
\text { (With corporation } \\
\text { control) }\end{array}$ & $\begin{array}{l}(6) \\
\text { (With control } \\
\text { firms }<5 \\
\text { years) }\end{array}$ & $\begin{array}{l}\text { (7) } \\
\text { (With other } \\
\text { size } \\
\text { quartiles) }\end{array}$ & $\begin{array}{l}\text { (8) } \\
\text { (Without } \\
\text { sunset } \\
\text { clause) }\end{array}$ & $\begin{array}{l}\text { (9) } \\
\text { (Unfriendly } \\
\text { context) }\end{array}$ \\
\hline \multirow[t]{2}{*}{ War years } & 0.89 & 0.82 & 0.90 & 0.89 & 0.80 \\
\hline & $(0.23)$ & $(0.22)$ & $(0.24)$ & $(0.24)$ & $(0.22)$ \\
\hline \multirow[t]{2}{*}{ Federal revenues } & 1.00 & 1.00 & 1.00 & 1.00 & 1.00 \\
\hline & $(0.00)$ & $(0.00)$ & $(0.00)$ & $(0.00)$ & $(0.00)$ \\
\hline \multirow[t]{2}{*}{ Board } & 0.73 & 0.68 & 0.68 & 0.71 & $0.66 \dagger$ \\
\hline & $(0.18)$ & $(0.17)$ & $(0.16)$ & $(0.17)$ & $(0.15)$ \\
\hline \multirow[t]{2}{*}{ Sunset clause } & $3.10 * *$ & $2.90 * *$ & $2.74 * *$ & & $2.42 *$ \\
\hline & (1.17) & (1.13) & $(1.00)$ & & $(0.87)$ \\
\hline \multirow{2}{*}{$\begin{array}{l}\text { Weak legislative } \\
\text { origin }\end{array}$} & $1.60 * *$ & $1.57 * *$ & $1.56^{* *}$ & $1.60 * *$ & $1.54 * *$ \\
\hline & $(0.19)$ & $(0.19)$ & $(0.19)$ & $(0.19)$ & $(0.19)$ \\
\hline \multirow{2}{*}{$\begin{array}{l}\text { Small agency (up } \\
\text { to } 25 \text { th percen- } \\
\text { tile) }\end{array}$} & $3.00 * *$ & $3.19 * *$ & $3.20 * *$ & $2.87 * *$ & $3.34 * *$ \\
\hline & $(0.77)$ & $(0.82)$ & $(0.98)$ & $(0.70)$ & $(0.86)$ \\
\hline $\begin{array}{l}\text { Medium agency } \\
\text { ( } 25 \text { th to } 50 \text { th } \\
\text { percentile) }\end{array}$ & & & $\begin{array}{c}0.87 \\
(0.33)\end{array}$ & & \\
\hline $\begin{array}{l}\text { Medium agency } \\
\text { (50th to } 75 \text { th } \\
\text { percentile) }\end{array}$ & & & $\begin{array}{l}1.12 \\
(0.42)\end{array}$ & & \\
\hline \multirow{2}{*}{$\begin{array}{l}\text { Mission state- } \\
\text { ment add. }\end{array}$} & 2.51 & 2.25 & 2.25 & 2.21 & 2.68 \\
\hline & $(3.17)$ & $(2.92)$ & $(3.13)$ & $(2.74)$ & $(3.54)$ \\
\hline \multirow{2}{*}{$\begin{array}{l}\text { Mission state- } \\
\text { ment rem. }\end{array}$} & 0.46 & 0.41 & 0.43 & 0.47 & 0.44 \\
\hline & $(0.35)$ & $(0.31)$ & $(0.33)$ & $(0.37)$ & $(0.33)$ \\
\hline
\end{tabular}


TABLE A1 (Continued)

\begin{tabular}{|c|c|c|c|c|c|}
\hline & $\begin{array}{l}\text { (5) } \\
\text { (With corporation } \\
\text { control) }\end{array}$ & $\begin{array}{l}(6) \\
\text { (With control } \\
\text { firms }<5 \\
\text { years) }\end{array}$ & $\begin{array}{l}\text { (7) } \\
\text { (With other } \\
\text { size } \\
\text { quartiles) }\end{array}$ & $\begin{array}{l}\text { (8) } \\
\text { (Without } \\
\text { sunset } \\
\text { clause) }\end{array}$ & $\begin{array}{l}(9) \\
\text { (Unfriendly } \\
\text { context) }\end{array}$ \\
\hline \multirow[t]{2}{*}{ No change } & 1.18 & 1.18 & 1.19 & 1.21 & 1.15 \\
\hline & $(0.30)$ & $(0.30)$ & $(0.31)$ & $(0.27)$ & $(0.31)$ \\
\hline \multirow{2}{*}{$\begin{array}{l}\text { Same-year } \\
\text { change }\end{array}$} & $9.17 * *$ & $9.17 * *$ & $8.90 * *$ & $7.35 * *$ & $10.35 * *$ \\
\hline & $(5.51)$ & $(5.58)$ & $(5.36)$ & $(4.51)$ & $(6.85)$ \\
\hline \multirow{2}{*}{$\begin{array}{l}\text { Reactive change } \\
\text { (2-year lag) }\end{array}$} & $0.13^{*}$ & $0.11^{*}$ & $0.12 *$ & $0.15 \dagger$ & $0.11 *$ \\
\hline & $(0.13)$ & $(0.12)$ & $(0.13)$ & $(0.15)$ & $(0.12)$ \\
\hline \multirow{2}{*}{$\begin{array}{l}\text { Proactive change } \\
\text { (2-year lead) }\end{array}$} & $3.82 * *$ & $3.82 * *$ & $4.05 * *$ & $4.86^{* *}$ & $3.15 *$ \\
\hline & (1.77) & $(1.75)$ & $(1.89)$ & $(2.33)$ & $(1.61)$ \\
\hline \multirow[t]{2}{*}{ Corporation } & 0.56 & & & & \\
\hline & $(0.27)$ & & & & \\
\hline \multirow[t]{2}{*}{ Young agencies } & & $2.71 \dagger$ & & & \\
\hline & & $(1.39)$ & & & \\
\hline \multirow{2}{*}{$\begin{array}{l}\text { Unfriendly } \\
\text { president }\end{array}$} & & & & & $0.42 * *$ \\
\hline & & & & & $(0.12)$ \\
\hline \multirow{2}{*}{$\begin{array}{l}\text { Unfriendly } \\
\text { majority }\end{array}$} & & & & & 0.96 \\
\hline & & & & & $(0.29)$ \\
\hline \multicolumn{6}{|l|}{$\begin{array}{l}\text { Same-year } \\
\text { change }\end{array}$} \\
\hline \multicolumn{6}{|l|}{$\begin{array}{l}\text { Reactive change } \\
\text { (1-year lag) }\end{array}$} \\
\hline \multicolumn{6}{|l|}{$\begin{array}{l}\text { Proactive change } \\
\text { (1-year lead) }\end{array}$} \\
\hline \multicolumn{6}{|l|}{$\begin{array}{l}\text { Reactive change } \\
\text { (2-year lag) }\end{array}$} \\
\hline \multicolumn{6}{|l|}{$\begin{array}{l}\text { Proactive change } \\
\text { (2-year lead) }\end{array}$} \\
\hline Log likelihood & -300.75 & -300.09 & -301.53 & -305.50 & -296.56 \\
\hline $\mathrm{Chi}^{2}$ & 93.50 & 98.80 & 94.78 & 84.78 & 93.85 \\
\hline AIC value & 627.50 & 626.18 & 630.06 & 633.00 & 621.12 \\
\hline Observations & 4,885 & 4,885 & 4,885 & 4,885 & 4,885 \\
\hline
\end{tabular}

Note. Hazard ratios are reported; robust standard errors in parentheses.

$\dagger p<.10, * p<.05, * * p<.01$. 
TABLE A2 List of agencies in the population

\begin{tabular}{|c|c|c|}
\hline Name of agency & Established & Terminated $^{\mathrm{a}}$ \\
\hline Action & 1-Jul-1971 & 31-Mar-1995 \\
\hline Administrative Conference of the U.S. I & 13-Apr-1961 & 31-Oct-1995 \\
\hline Administrative Conference of the U.S. II & 3-Mar-2010 & Still exists \\
\hline Aeronautical Board & 11-Okt-1916 & 27-Jul-1948 \\
\hline African Development Foundation & 20-Nov-1980 & Still exists \\
\hline Agricultural Adjustment Administration & 12-Jun-1933 & 26-Jul-1945 \\
\hline Atomic Energy Commission & 1-Aug-1946 & 11-Oct-1974 \\
\hline Board of Surveys and Maps of the Federal Government & 30-Dec-1919 & 10-Mar-1942 \\
\hline Board of War Communications & 24-Sep-1940 & 24-Feb-1947 \\
\hline Broadcasting Board of Governors & 1-Oct-1999 & Still exists \\
\hline Canal Zone Government & 24-Aug-1912 & 27-Sep-1979 \\
\hline Central Intelligence Agency & 26-Jul-1947 & Still exists \\
\hline Central Statistical Board & 9-Aug-1933 & 25-Jul-1940 \\
\hline Civil Aeronautics Board (former Civil Aeronautics Authority) & 23-Jun-1938 & 4-Oct-1984 \\
\hline Civil Defense Coordinating Board & 11-May-1955 & 1-Jul-1958 \\
\hline $\begin{array}{l}\text { Civilian Conservation Corps (former Emergency Conserva- } \\
\text { tion Work) }\end{array}$ & 5-Apr-1933 & 2-Jul-1942 \\
\hline Commodity Credit Corporation & 16-Oct-1933 & Still exists \\
\hline Commodity Futures Trading Commission & 23-Oct-1974 & Still exists \\
\hline Community Services Administration & 4-Jan-1975 & 13-Aug-1981 \\
\hline Consumer Product Safety Commission & 27-Oct-1972 & Still exists \\
\hline Corporation for National and Community Service & 1-Oct-1993 & Still exists \\
\hline Defense Nuclear Facilities Safety Board & 29-Sep-1988 & Still exists \\
\hline Development Loan Fund & 14-Aug-1957 & 4-Sep-1961 \\
\hline Displaced Persons Commission & 25-Jun-1948 & 31-Aug-1952 \\
\hline Economic Cooperation Administration & 3-Apr-1948 & 10-Oct-1951 \\
\hline Electric Home and Farm Authority & 12-Aug-1935 & 13-Oct-1942 \\
\hline Energy Research and Development Administration & 11-Oct-1974 & 4-Aug-1977 \\
\hline Environmental Protection Agency & 2-Dec-1970 & Still exists \\
\hline Equal Employment Opportunity Commission & 2-Jul-1964 & Still exists \\
\hline Export Import Bank & 2-Feb-1934 & Still exists \\
\hline Farm Credit Administration & 27-Mar-1933 & Still exists \\
\hline Federal Aviation Agency & 28-Aug-1958 & Still exists \\
\hline Federal Board of Hospitalization & 1-Nov-1921 & 30-Jun-1948 \\
\hline Federal Civil Defense Administration & 1-Dec-1950 & 1-Jun-1958 \\
\hline Federal Coal Mine Safety Board of Review & 16-Jul-1952 & 30-Mar-1970 \\
\hline
\end{tabular}


TABLE A2 (Continued)

\begin{tabular}{|c|c|c|}
\hline Name of agency & Established & Terminated $^{\mathrm{a}}$ \\
\hline Federal Communications Commission & 19-Jun-1934 & Still exists \\
\hline Federal Coordinator of Transportation & 16-Jun-1933 & 16-Jun-1936 \\
\hline Federal Deposit Insurance Corporation & 16-Jun-1933 & Still exists \\
\hline Federal Election Commission & $15-O c t-1974$ & Still exists \\
\hline Federal Emergency Management Agency & 31-Mar-1979 & Still exists \\
\hline Federal Emergency Relief Administration & 12-May-1933 & 30-Jun-1938 \\
\hline Federal Energy Administration & 7-May-1974 & 4-Aug-1977 \\
\hline Federal Home Loan Bank Board & 22-Jul-1932 & 9-Aug-1989 \\
\hline Federal Housing Administration & 27-Jun-1934 & 9-Sep-1965 \\
\hline Federal Housing Finance Agency & 30-Jul-2008 & Still exists \\
\hline Federal Housing Finance Board & 9-Aug-1989 & 30-Jul-2008 \\
\hline Federal Labor Relations Authority & 1-Jan-1979 & Still exists \\
\hline Federal Land Bank Commissioner & 17-Jul-1916 & 6-Aug-1953 \\
\hline Federal Loan Agency & 1-Jul-1939 & 30-Jun-1947 \\
\hline Federal Maritime Commission & 12-Aug-1961 & Still exists \\
\hline Federal Mediation and Conciliation Service & 23-Jun-1947 & Still exists \\
\hline Federal Mine Safety and Health Review Commission & 9-Nov-1977 & Still exists \\
\hline Federal Power Commission & 23-Jun-1930 & 4-Aug-1977 \\
\hline Federal Prison Industries Incorporated & 11-Dec-1934 & Still exists \\
\hline Federal Reserve & 23-Dec-1913 & Still exists \\
\hline Federal Retirement Thrift Investment Board & 6-Jun-1986 & Still exists \\
\hline Federal Security Agency & 1-Jul-1939 & 11-Apr-1953 \\
\hline Federal Surplus Commodities Corporation & 16-Jun-1933 & 30-Jun-1940 \\
\hline Federal Trade Commission & 26-Sep-1914 & Still exists \\
\hline Foreign Claims Settlement Commission & 1-Jul-1954 & Still exists \\
\hline Foreign Operations Administration & 1-Aug-1953 & 9-May-1955 \\
\hline $\begin{array}{l}\text { General Accounting Office (former Government Account- } \\
\text { ability Office) }\end{array}$ & 10-Jun-1921 & Still exists \\
\hline General Services Administration & 1-Jul-1949 & Still exists \\
\hline Government Patents Board & 23-Jan-1950 & 24-Mar-1961 \\
\hline Government Printing Office & 03-Apr-1861 & Still exists \\
\hline Housing and Home Finance Agency & 27-Jul-1947 & 9-Sep-1965 \\
\hline Interstate Commerce Commission & 7-Feb-1887 & 29-Dec-1995 \\
\hline Maritime Labor Board & 23-Jun-38 & 22-Jun-1942 \\
\hline $\begin{array}{l}\text { Merit System Protection Board (former Civil Service } \\
\text { Commission) }\end{array}$ & 16-Jan-1883 & Still exists \\
\hline Motor Carrier Claims Commission & 2-Jun-1948 & 31-Dec-1952 \\
\hline
\end{tabular}


TABLE A2 (Continued)

\begin{tabular}{|c|c|c|}
\hline Name of agency & Established & Terminated $^{\mathrm{a}}$ \\
\hline National Aeronautics and Space Administration & 29-Jul-1958 & Still exists \\
\hline National Archives and Records Administration & 19-Jun-1934 & Still exists \\
\hline National Bituminous Coal Commission & 30-Aug-1935 & 1-Jul-1939 \\
\hline $\begin{array}{l}\text { National Capital Housing Authority (former Alley Dwelling } \\
\text { Authority) }\end{array}$ & 12-Jun-1934 & 1-Jul-1974 \\
\hline $\begin{array}{l}\text { National Capital Planning Commission (former National } \\
\text { Capital Park and Planning Commission) }\end{array}$ & 6-Jun-1924 & Still exists \\
\hline National Credit Union Administration & 10-Mar-1970 & Still exists \\
\hline National Emergency Council & 17-Nov-1933 & 1-Jul-1939 \\
\hline National Forest Reservation Commission & 1-Mar-1911 & 22-Oct-1976 \\
\hline National Foundation for the Arts and the Humanities & 29-Sep-1965 & Still exists \\
\hline National Historical Publications Commission & 19-Jun-1934 & Still exists \\
\hline National Housing Agency & 24-Feb-1942 & 27-Jul-1947 \\
\hline National Labor Relations Board & 5-Jul-1935 & Still exists \\
\hline National Mediation Board & 21-Jul-1934 & Still exists \\
\hline National Railroad Passenger Corporation (Amtrak) & 30-Oct-1970 & Still exists \\
\hline National Recovery Administration & 16-Jun-1933 & 21-Dec-1935 \\
\hline National Science Foundation & 10-May-1950 & Still exists \\
\hline National Security Training Commission & 19-Jun-1951 & 25-Mar-1957 \\
\hline National Transportation Safety Board & 15-Oct-1966 & Still exists \\
\hline National Youth Administration & 26-Jun-1935 & 12-Jul-1943 \\
\hline Nuclear Regulatory Commission & 15-Jan-1975 & Still exists \\
\hline Occupational Safety and Health Review Commission & 28-Apr-1971 & Still exists \\
\hline Office of Censorship & 19-Dec-1941 & 28-Sep-1945 \\
\hline Office of Government Ethics & 26-Oct-1978 & Still exists \\
\hline $\begin{array}{l}\text { Office of Management and Budget (former Bureau of the } \\
\text { Budget) }\end{array}$ & 10-Jun-1921 & Still exists \\
\hline Office of Personnel Management & 28-Dec-1978 & Still exists \\
\hline Office of Price Administration & 11-Apr-1941 & 12-Dec-1946 \\
\hline Office of Special Counsel & 1-Jan-1979 & Still exists \\
\hline Office of the Director of National Intelligence & 22-Apr-2005 & Still exists \\
\hline Office of the Housing Expediter & 22-May-1946 & 31-Jul-1951 \\
\hline Office of War Mobilization and Reconversion & 3-Oct-1944 & 12-Dec-1946 \\
\hline Overseas Private Investment Corporation & 19-Jan-1971 & Still exists \\
\hline Panama Canal Commission & 29-Jun-1948 & 30-Sep-2004 \\
\hline Peace Corps & 1-Mar-1961 & Still exists \\
\hline Pennsylvania Avenue Development Corporation & 27-Oct-1972 & 1-Apr-1996 \\
\hline
\end{tabular}


TABLE A2 (Continued)

\begin{tabular}{|c|c|c|}
\hline Name of agency & Established & Terminated $^{\mathbf{a}}$ \\
\hline Pension Benefit Guaranty Corporation & 2-Sep-1974 & Still exists \\
\hline Petroleum Administration for War & 2-Dec-1942 & 3-Мay-1946 \\
\hline $\begin{array}{l}\text { Petroleum Administrative Board (former Petroleum Admin- } \\
\text { istration) }\end{array}$ & 11-Sep-1933 & 31-Mar-1936 \\
\hline $\begin{array}{l}\text { Postal Regulatory Commission (former Postal Rate Com- } \\
\text { mission) }\end{array}$ & 12-Aug-1970 & Still exists \\
\hline President's War Relief Control Board & 25-Jul-1942 & 14-May-1946 \\
\hline Prison Industries Reorganization Commission/Administration & 26-Sep-1935 & 30-Jun-1938 \\
\hline Railroad Retirement Board & 29-Aug-1935 & Still exists \\
\hline Reconstruction Finance Corporation & 22-Jan-1932 & 30-Jun-1957 \\
\hline Renegotiation Board & 25-Mar-1951 & 10-Oct-1978 \\
\hline Resettlement Administration & 30-Apr-1935 & 1-Jan-1946 \\
\hline Resolution Trust Corporation & 9-Aug-1989 & 31-Dec-1995 \\
\hline Rubber Producing Facilities Disposal Commission & 7-Aug-1953 & 20-Sep-1956 \\
\hline Rural Electrification Administration & 11-May-1935 & 20-Oct-1994 \\
\hline Saint Lawrence Seaway Development Corporation & 13-May-1954 & Still exists \\
\hline Securities and Exchange Commission & 2-Jul-1934 & Still exists \\
\hline Selective Service System & 16-Sep-1940 & Still exists \\
\hline Small Business Administration & 30-Jun-1953 & Still exists \\
\hline Social Security Administration & 14-Aug-1935 & Still exists \\
\hline Subversive Activities Control Board & 23-Sep-1950 & 30-Jun-1973 \\
\hline Tennessee Valley Authority & 18-May-1933 & Still exists \\
\hline $\begin{array}{l}\text { Thrift Depositor Protection Oversight Board (former Over- } \\
\text { sight Board for the Resolution Trust Corporation) }\end{array}$ & 9-Aug-1989 & 29-Jul-1998 \\
\hline Trade and Development Agency & 1-Jul-1980 & Still exists \\
\hline United States Agency for International Development & 3-Nov-1961 & Still exists \\
\hline United States Arms Control and Disarmament Agency & 26-Sep-1961 & 21-Oct-1998 \\
\hline Unites States Board of Tax Appeals & 2-Jun-1924 & Still exists \\
\hline $\begin{array}{l}\text { United States Commission on Civil Rights (former Com- } \\
\text { mission on Civil Rights) }\end{array}$ & 9-Sep-1957 & Still exists \\
\hline United States Employees Compensation Commission & 7-Sep-1916 & 16-Jul-1946 \\
\hline Unites States Information Agency I & 1-Aug-1953 & 1-Apr-1978 \\
\hline Unites States Information Agency II & 1-Apr-1978 & 1-Oct-1999 \\
\hline $\begin{array}{l}\text { Unites States International Trade Commission (former US } \\
\text { Tariff Commission) }\end{array}$ & 8-Sep-1916 & Still exists \\
\hline United States Maritime Commission & 29-Jun-1936 & 24-May-1950 \\
\hline United States Metric Board & 23-Dec-1975 & 1-Oct-1982 \\
\hline United States Postal Service & $22-09-1789$ & Still exists \\
\hline
\end{tabular}


TABLE A2 (Continued)

\begin{tabular}{|lcc|}
\hline Name of agency & Established & Terminated $^{\mathbf{a}}$ \\
\hline United States Railroad Administration & 29-Aug-1916 & 1-Jul-1939 \\
\hline Veterans Administration & 3-Jul-1930 & Still exists \\
\hline Veterans Education Appeals Board & 13-Jul-1950 & 28-Aug-1957 \\
\hline Virgin Islands Corporation & 30-Jun-1949 & 1-Jul-1966 \\
\hline War Finance Corporation & 5-Aug-1918 & 1-Jul-1939
\end{tabular}

a"Still exists" refers to the end date of our study (31-Dec-2011). 